\title{
SEISMIC STUDY OF MODHERA SUN TEMPLE
}

\author{
Rudra Upadhyay $^{1}$, Sandip Kapadiya ${ }^{2}$, Vasudeo Chaudhari ${ }^{3}$ \\ ${ }^{1}$ Student, Civil Engineering, Gandhinagar Institute of Technology, Gujarat, India \\ ${ }^{2}$ Assistant Professor Civil Engineering, Gandhinagar Institute of Technology, Gujarat, India \\ ${ }^{3}$ Assistant Professor Civil Engineering, Indus University, Gujarat, India
}

\begin{abstract}
Monuments have been created for thousands of years, and they are often the most durable and famous symbols of ancient civilizations. They have witnessed many earthquakes with ominously less damage. The purpose of this project is to analyze the static and dynamic properties of ancient Indian monuments. For that purpose Modhera Sun Temple, Gujarat has been taken as the Monument. The 3D modelling and analysis is done by using Sap2000V.15 software. Seismic Co-efficient analysis, modal analysis and Time History analysis is performed on the model.
\end{abstract}

Keywords: Modhera Sun Temple, Monument, Time History, El Centro, Modal Analysis

\section{INTRODUCTION}

Monuments have been created for thousands of years, and they are often the most durable and famous symbols of ancient civilizations. India is one of the oldest country and many monuments are present in its soil. Majority of the monuments are located on seismically active region of intensity 2 and 3 for example north and west region of Indian Continent. Amongst them Gujarat has many important monuments which played important part in Indian history. The monument here chosen for study is Modhera sun temple which was constructed in 1026 A.D. It is situated in Mahesana district under seismic zone IV. It is oldest sun temple in the world. There are three parts of this sun temple Ramakunda, Nritya Mandapa and Sun temple. It has faced many historical earthquake events. $52 \%$ of the structure was damaged in the various foreign invasions but it was restored by Gujarat government in 1972 but the new restored part was damaged during the 2001 Bhuj Earthquake where as old construction remained safe. Aim of this work is to do comparative study of seismic behavior for normal structure and monument and hence for that, here sun temple has been taken as the monument. There are main three ways of doing seismic analysis of the structure, Linear Static Analysis, Response Spectrum and Time History Analysis. Modal analysis is been performed on the model of monument and regarding to that, data of frequency and time period variance with the change of modes is studied. Characteristics of El Centro time history are applied to the Sun Temple and its effect on monument is evaluated by response spectrum method and time history method.

\section{METHODOLOGY}

F.E.M. based software Sap2000 have been used for the modelling of the Modhera Sun Temple. Effect of the essential parameter like deflection, pseudo acceleration, time period, frequency were studied by applying el-Centro time history, which is applied as ground motion and effects of different parameters are studied on dome and openings.

\section{MODELLING}

The model of Modhera sun temple is been prepared in the F.E.M. base software Sap2000V15. To reduce the complexity in the analysis elements are assumed perfectly bonded. For creating 3D model of Modhera sun temple solid block components have been taken and properties of sandstone material are assigned to them. Model is been prepared using structural data provided by Archaeological Survey of India

\subsection{Model Dimensions}

Model of sun temple is prepared as fix base model. In plan, shape of base of the structure looks like two lotuses. Two columns are located in the entrance. There are 18 different columns inside the structure. 8 main columns take the load of the dome and remaining 10 columns are connected with main columns via beams for transferring the load of dome to foundation. Due to carving columns are in hexagonal shape but to avoid complexity in modeling, columns are taken as square element by keeping equivalent area as hexagonal.

Table1 Model Dimensions ${ }^{[8]}$

\begin{tabular}{|c|c|}
\hline Element & Dimensions \\
\hline Plinth & $2.03 \mathrm{~m}$ \\
\hline Length & $22.4 \mathrm{~m}$ \\
\hline Width & $12.7 \mathrm{~m}$ \\
\hline
\end{tabular}




\begin{tabular}{|c|c|}
\hline No. of Columns & 18 \\
\hline Height of Column & $6.3 \mathrm{~m}$ \\
\hline Slab Thickness & $1.02 \mathrm{~m}$ \\
\hline Foundation Thickness & $3 \mathrm{~m}$ \\
\hline Height & $8.8 \mathrm{~m}$ \\
\hline Height of dome & $1.5 \mathrm{~m}$ \\
\hline Seal level & $1 \mathrm{~m}$ \\
\hline Size of Column & $0.8 \mathrm{~m} \mathrm{X} 0.8 \mathrm{~m}$ \\
\hline
\end{tabular}

\subsection{Material Modelling}

Material used in Modhera sun temple is sandstone found near Kadi, Mahesana district and various properties of the sandstone is enlisted as below

Table2. Material Characteristics of Sand Stone [9]

\begin{tabular}{|c|c|}
\hline Term & Value \\
\hline Modulus of Elasticity & $9700 \mathrm{Mpa}$ \\
\hline Poisson's Ratio & 0.3 \\
\hline Self-Weight & $21.57 \mathrm{kN} / \mathrm{m}^{3}$ \\
\hline
\end{tabular}

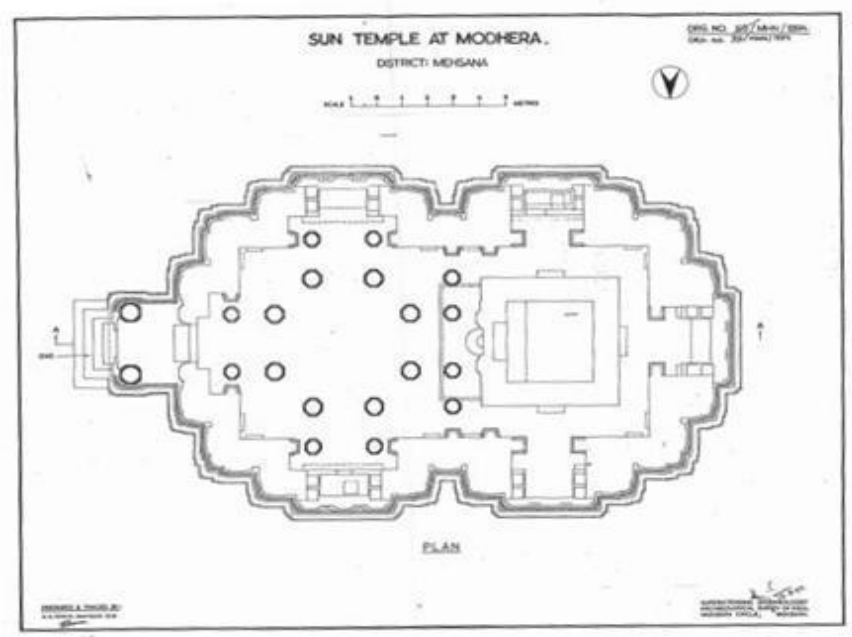

Fig1. Plan of modhera sun temple
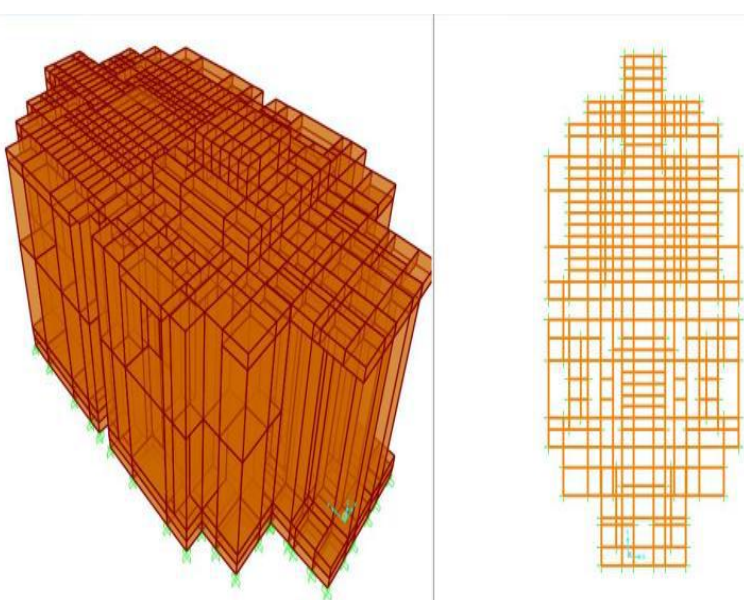

Fig2. 3D model and Plan of Modhera Sun Temple in Sap2000V15

\section{SCOPE OF THE WORK}

To determine effect of earthquake on monument seismic study has been carried out. The main parameter here considered is the effect of El-Centro time-history on the dome and openings in Modhera sun temple. Three types of analysis Linear Static, Modal Analysis and Time-History are carried out and based on output, variance in time period and frequency with the change in different modes are studied as well as graphs are prepared of deflection v/s time-period and pseudo-acceleration v/s time-period.

\section{RESULTS AND DISCUSSION}

\subsection{Seismic Co-efficient Method}

Being most primitive and mostly used in India seismic coefficient method was used to analyze on the model. To study the inertia force generated on the foundation of Modhera Sun Temple considering all the factors as mentioned in IS 1893:2002 base shear was calculated. The base shear value is considerably very high in compare to normal residential structure of same dimension. The reason of high base shear is due less time period, high Importance factor, high zone factor as well as high self-weight.

Table3. Base Shear and Moment Values

\begin{tabular}{|l|l|l|l|}
\hline & $\begin{array}{l}\text { Force in X } \\
\text { Direction }\end{array}$ & $\begin{array}{l}\text { Force in Y } \\
\text { Direction }\end{array}$ & $\begin{array}{l}\text { Force in Z } \\
\text { Direction }\end{array}$ \\
\hline Max & $5139.753 \mathrm{kN}$ & $4086.583 \mathrm{kN}$ & $2359.744 \mathrm{kN}$ \\
\hline Min & $-5660.51 \mathrm{kN}$ & $-4684.86 \mathrm{kN}$ & $-2444.12 \mathrm{kN}$ \\
\hline
\end{tabular}




\subsection{Model Analysis}

To study the frequency and time variance of sun temple under different mode shapes Modal Analysis has been carried out. Total 10 different mode shapes were studied. It can be seen that there is increase in frequency as the mode shape changes. Increase in frequency can be understood as mode shape changes, stiffness changes of structure which leads to stiffer structure and as joints are well defined with each other structure behaves like one unit due to which structure tends to be more flexible which results into high frequency.

Table4. Modal Analysis Results

\begin{tabular}{|l|l|l|l|l|}
\hline $\begin{array}{l}\text { Step } \\
\text { Num }\end{array}$ & $\begin{array}{l}\text { Period } \\
\text { (second })\end{array}$ & $\begin{array}{l}\text { Frequency } \\
\text { Cyc/sec) }\end{array}$ & $\begin{array}{l}\text { Circular } \\
\text { Frequency } \\
\text { (rad/sec) }\end{array}$ & $\begin{array}{l}\text { Modal } \\
\text { Stiffness } \\
\text { kN-m) }\end{array}$ \\
\hline 1 & 0.072723 & 13.751 & 86.399 & 7464.74903 \\
\hline 3 & 0.058337 & 17.142 & 107.71 & 11600.50526 \\
\hline 4 & 0.049239 & 20.309 & 127.6 & 16282.99826 \\
\hline 5 & 0.038611 & 25.9 & 162.73 & 26481.62496 \\
\hline 6 & 0.033558 & 28.102 & 176.57 & 31178.01686 \\
\hline 7 & 0.031139 & 32.114 & 201.78 & 40713.51022 \\
\hline 8 & 0.028872 & 34.636 & 217.62 & 47360.00247 \\
\hline 9 & 0.026815 & 37.292 & 234.31 & 54902.50674 \\
\hline 10 & 0.026696 & 37.459 & 235.36 & 55395.48211 \\
\hline
\end{tabular}

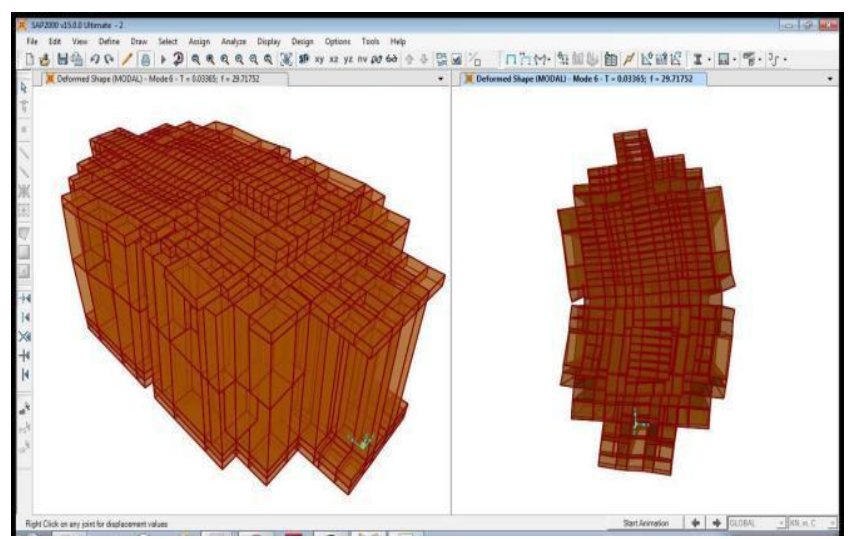

Fig3. $1^{\text {st }}$ Mode Shape of Modhera Sun Temple

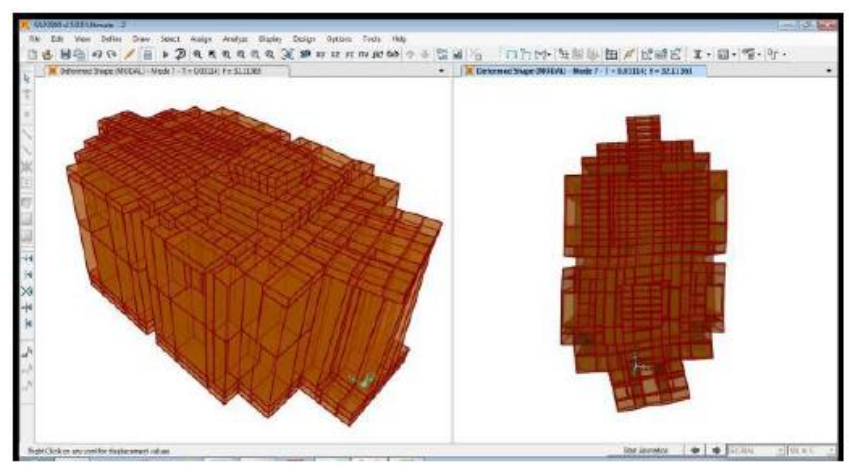

Fig4. $2^{\text {nd }}$ Mode Shape of Modhera Sun Temple

\subsection{Time-History Analysis}

To study the behavior of monument under the earthquake, elCentro time-history is applied to the monument and deflection, development of stresses and behavior of structure is studied. These parameters are studied on dome and on openings as they are most vulnerable in shear loading. After the application of the time-history, stress distribution diagram was plotted in which it can be seen that stress distribution on whole temple is almost equal except dome portion (Fig 6) so further parametric study was carried out on dome. It can be seen that maximum pseudo acceleration on the dome was almost equal to $0.3 \mathrm{~g}$ (Fig 7) where as maximum deflection was almost $0.6 \mathrm{~mm}$ (Fig 8). Reason of such earthquake resistant behavior of monument is due to well defined joint of columns with the slab, high number of columns to transfer load to the ground as well as the lower stiffness of structure which makes structure flexible and leads to less deflection but high frequency. In monument no adhesive or mortar is provided to join two sandstones, instead of mortar, similar to curved shape butt joint is provided and wooden stick of sag tree is used as joint as shown in fig 9. In addition Connections between main columns are shown in Fig 10.
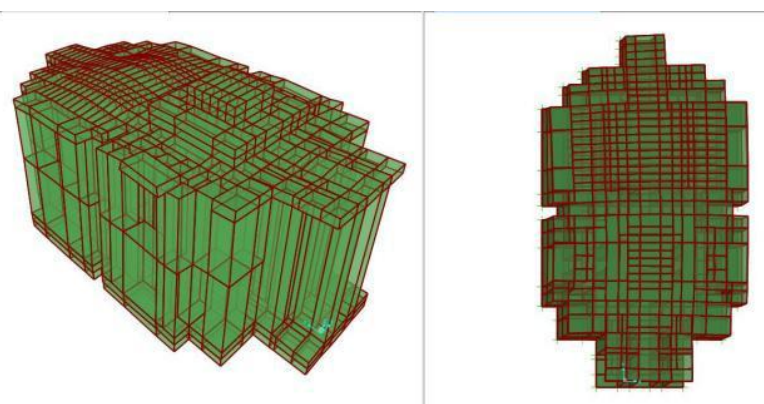

Fig 5.Deformed Shape of Modhera Sun Temple under El Centro Earthquake 

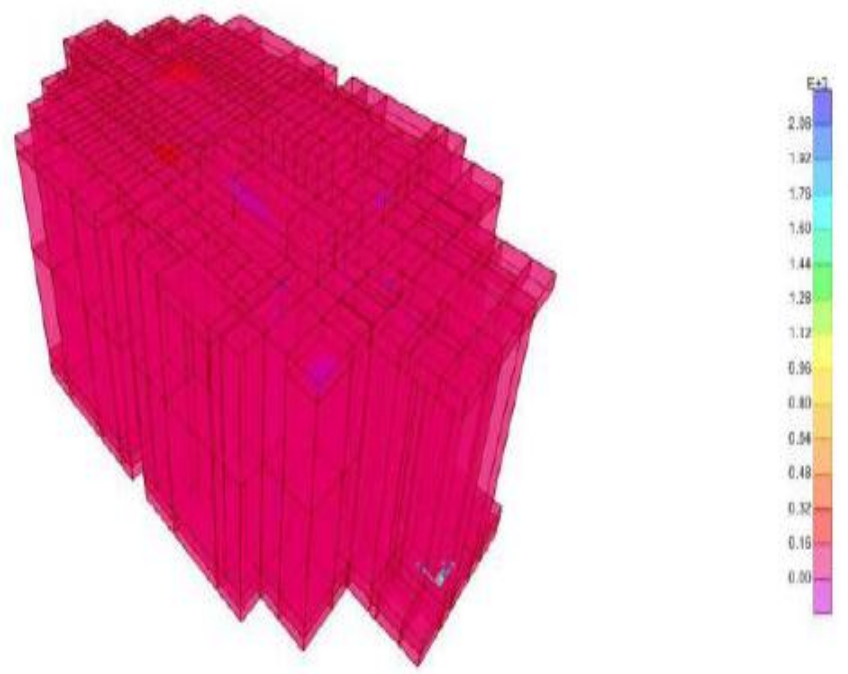

Fig6. Stress Distribution Diagram of Modhera Sun Temple under El Centro Earthquake

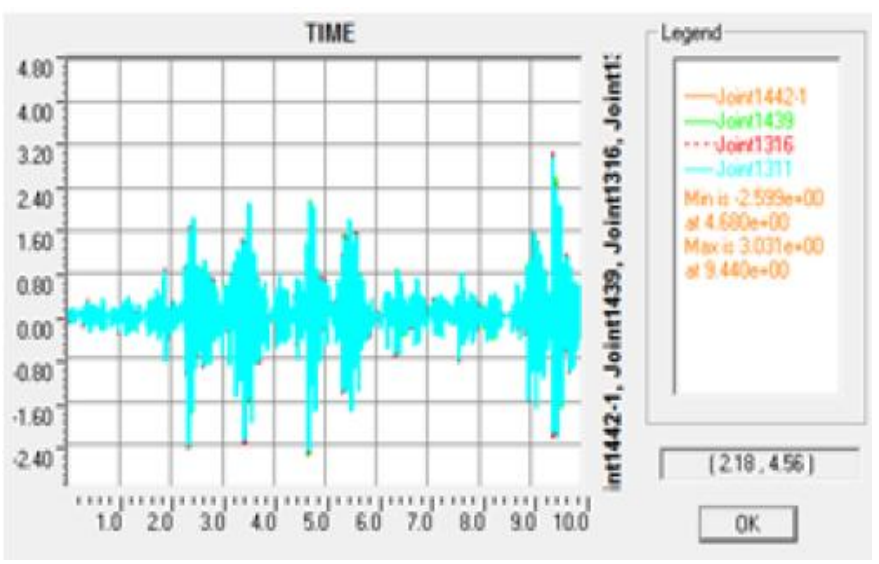

Fig7.Time History curve for A Pseudo Acceleration in respect to time for dome of Modhera Sun Temple

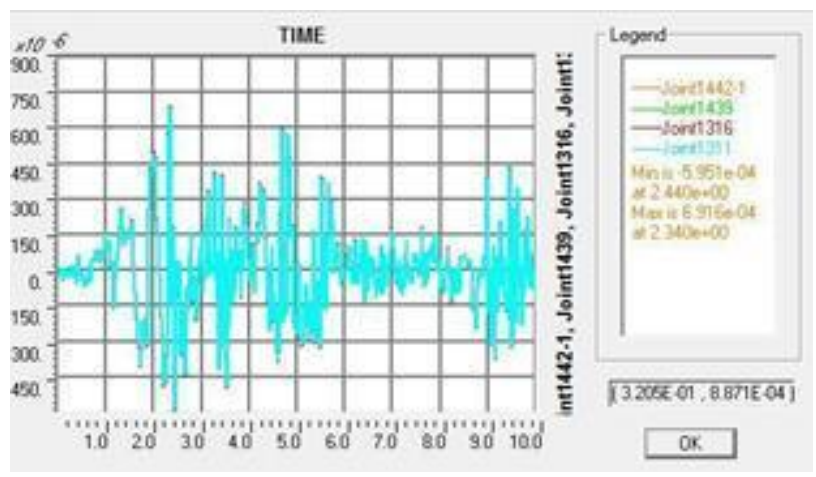

Fig8. Time History curve for Acceleration in respect to time for dome of Modhera Sun Temple
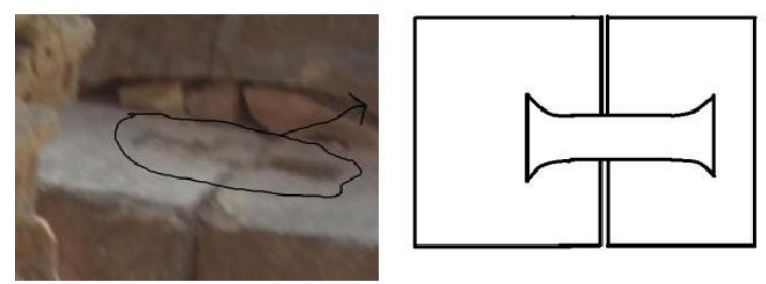

Fig9. Uses of wooden sticks as sandstone joint material

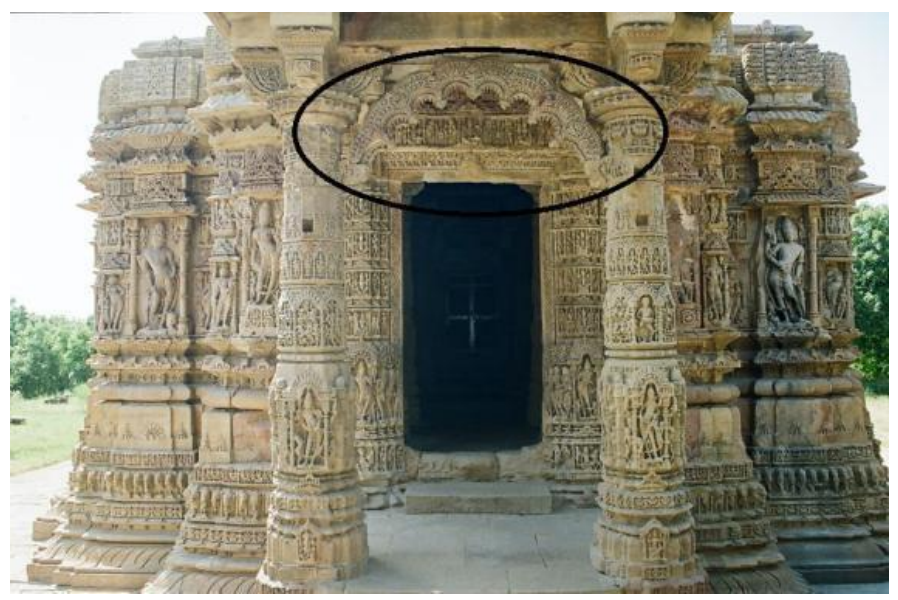

Fig10. Artistic earthquake resistant connections between two columns

\section{CONCLUSIONS}

Here 3D model of sun temple is been prepared in SAP2000 to find out different mode shapes and to do time history analysis. Time History of El Centro earthquake was applied to the monument. Though it has high Pseudo acceleration due to well defined joins between slab and column it registered negligible deflection

\section{REFERENCES}

[1] R.N.Dubey, Shashi Thakkar, Akash Gupta, Seismic Analysis Of The Safety evaluation of the Taj Mahal,11th world conference of Earthquake Engineering.

[2] Jag MohanHumar, Dynamic Analysis of Buildings for Earthquake Resistant Design

[3] Anil K Chopra, Dynamics of the Structure, ISBN 97881-317-1329

[4] Mario Paz, Structural Dynamics, ISBN 81-239-09-780

[5] Report on 1985 Mexico City Earthquake from "EQ Facts \& Lists: Large Historical Earthquakes", USGS.

[6] Newark, N. M., and Hall, W. J. 1982. "Earthquake Spectra and Design," Engineering Monographs on Earthquake Criteria, Structural Design, and Strong Motion Records, Vol 3, Earthquake Engineering Research Institute, Oakland, CA. 
[7] Lin, Rong-Gong; Allen, Sam (26 February 2011). "New Zealand quake raises questions about L.A.buildings". Los Angeles Times (Tribune). Retrieved

[8] Structural Details from Archeological Survey of India

[9] Dr. K.R. Arora, Soil Mechanics and Foundation Engineering, ISBN 81- 8014-112- 8

[10] R.G.Flesch, Earthquake Resistant Design Of High Rise Building 